\title{
KETEGARAN UJI-t TERHADAP KETIDAKNORMALAN DATA
}

\author{
Agus Santoso \\ Universitas Negeri Yogyakarta
}

\begin{abstract}
t-test used to test means of two populations assumes that each population is normally distributed. Theoretically, violation of the assumption makes the result of the test invalid. This research evaluates the robustness of the t-test on various value of sample size using three types of distribution: normal, symmetric non-normal, and not symmetric non-normal. Different computation techniques of $t$-value which depend on the variance of the two populations were also employed. The simulation showed that $t$-test used to test mean of two populations is not influenced by non-normality of the population distribution. The exploration of distribution of the difference between two samples means showed that its distribution was normal. Therefore, the robustness against non-normality of the $t$-test was the consequences of the difference between two sample means that normally is distributed.
\end{abstract}

Key words: central limit theorem, normality, robust, t-test for two population means

Dalam mempelajari karakteristik suatu populasi seringkali sudah ada dugaan tertentu terhadap populasi tersebut yang tertuang dalam hipotesis. Apabila populasi yang dipelajari ada dua dan karakter populasi yang jadi kajian adalah nilai tengahnya, maka hipotesis tersebut dapat berupa nilai tengah populasi pertama lebih besar dari populasi kedua, atau nilai tengah populasi pertama lebih kecil dari populasi kedua, atau nilai tengah kedua populasi tidak sama. Dalam notasi matematika, ketiga tipe hipotesis tersebut dapat ditulis sebagai berikut.
a. $H_{0}: \mu_{1} \leq \mu_{2} \quad$ vs $H_{1}: \mu_{1}>\mu_{2}$
b. $H_{0}: \mu_{1} \geq \mu_{2}$ vs $H_{1}: \mu_{1}<\mu_{2}$
c. $H_{0}: \mu_{1}=\mu_{2} \quad$ vs $H_{1}: \mu_{1} \neq \mu_{2}$

Untuk menguji hipotesis tersebut dapat digunakan Uji t, Uji Mann-Whitney, atau Uji KruskalWallis. Dari ketiga Uji tersebut, Uji t memiliki kuasa uji lebih besar dibandingkan dua uji lainnya (Siege \& Castellan,1988). Hal ini berarti bahwa Uji t pada taraf nyata yang sama, lebih mampu mendeteksi hipotesis $\mathrm{H}_{1}$ yang memang benar dibanding Uji Mann-Whitney atau Uji Kruskal-Wallis. Hal ini yang menyebabkan Uji t lebih sering digunakan dibandingkan dua uji lainnya. Hanya saja, Uji t mengasumsikan bahwa data yang akan diuji menyebar normal, tidak seperti dua uji lainnya yang tidak memerlukan asumsi kenormalan tersebut.

Pada beberapa penelitian ketegaran uji yang memerlukan asumsi kenormalan, disebutkan bahwa uji semacam itu tegar terhadap ketidaknormalan data selama sebaran data simetris. Nasoetion (2000) mengemukakan bahwa pada kasus percobaan faktor tunggal dalam RAL, pelanggaran asumsi kenormalan masih dapat ditolerir asalkan galat percobaan masih simetris. Sedangkan Suryabuanaputra (2001) menunjukkan hasil yang senada pada kasus uji nilai tengah satu populasi. 
Dari beberapa hasil penelitian tersebut, menarik untuk mengkaji ketegaran terhadap ketidaknormalan data dari Uji t pada pengujian hipotesis nilai tengah dua populasi.

Sebagaimana dikemukakan, terdapat tiga tipe hipotesis nilai tengah dua populasi, yaitu
a. $\mathrm{H}_{0}: \mu_{1} \leq \mu_{2} \quad$ vs $\mathrm{H}_{1}: \mu_{1}>\mu_{2}$
b. $H_{0}: \mu_{1} \geq \mu_{2}$ vs $H_{1}: \mu_{1}<\mu_{2}$
c. $\mathrm{H}_{0}: \mu_{1}=\mu_{2} \quad$ vs $\mathrm{H}_{1}: \mu_{1} \neq \mu_{2}$

Ketiga tipe hipotesis tersebut dapat juga dituliskan menjadi

a. $H_{0}: \mu_{1}-\mu_{2} \leq 0$ vs $H_{1}: \mu_{1}-\mu_{2}>0$

b. $H_{0}: \mu_{1}-\mu_{2} \geq 0$ vs $H_{1}: \mu_{1}-\mu_{2}<0$

c. $H_{0}: \mu_{1}-\mu_{2}=0$ vs $H_{1}: \mu_{1}-\mu_{2} \neq 0$

Dari tiga tipe tersebut, tipe a dan b sering disebut sebagai hipotesis satu arah karena kisaran selisih nilai tengah yang dinyatakan pada hipotesis $\mathrm{H}_{1}$ adalah satu arah, yaitu kurang dari nol atau lebih dari nol; sedangkan tipe $\mathrm{c}$ disebut sebagai hipotesis dua arah karena kisaran selisih nilai tengah yang dinyatakan pada hipotesis $\mathrm{H}_{1}$ adalah dua arah (tidak sama dengan nol dapat berarti lebih dari nol atau kurang dari nol).

Pengujian yang dilakukan pada Uji t pada dasarnya menghitung selisih nilai tengah sampel yang ditarik secara acak dari masing-masing populasi $\left(\bar{X}_{1}-\bar{X}_{2}\right)$ sebagai dugaan bagi selisih nilai tengah populasinya $\left(\mu_{1}-\mu_{2}\right)$, kemudian membandingkannya dengan kisaran nilai pada hipotesis $\mathrm{H}_{0}$. Apabila nilai selisih ini sejalan dengan kisaran nilai pada $\mathrm{H}_{0}$, dapat dikatakan bahwa data mendukung $\mathrm{H}_{0}$. Untuk mengatasi masalah satuan pengukuran yang ada pada selisih nilai tengah sampel ini serta untuk mengakomodasi besarnya ragam data, nilai selisih ini dibagi terlebih dahulu dengan galat bakunya. Ide ini terlihat dari formula statistik uji thitung yang digunakan untuk pengujian yang dapat dituliskan sebagai berikut ini. $\mathrm{t}_{\text {hitung }}=\frac{\left(\overline{\mathrm{X}}_{1}-\overline{\mathrm{X}}_{2}\right)}{\mathrm{SE}}$ di mana SE adalah galat baku bagi $\left(\overline{\mathrm{X}}_{1}-\overline{\mathrm{X}}_{2}\right)$

Besarnya nilai SE ini tergantung ragam kedua populasi apakah dapat dianggap sama ataukah tidak. Kesamaan ragam kedua populasi ini diperiksa dengan Uji $\mathrm{F}$ dengan hipotesis yang diuji adalah $\mathrm{H}_{0}: \sigma_{1}^{2}=\sigma_{2}^{2}$ vs $\mathrm{H}_{1}: \sigma_{1}^{2} \neq \sigma_{2}^{2}$

Formula statistik uji $F_{\text {hitung yang digunakan adalah } F_{\text {hitung }}}=\frac{\max \left\{S_{1}^{2}, S_{2}^{2}\right\}}{\min \left\{S_{1}^{2}, S_{2}^{2}\right\}}$

Dengan $S_{1}^{2}$ dan $S_{2}^{2}$ masing-masing adalah ragam sampel dari populasi 1 dan populasi 2 dan $F_{\text {hitung }} \sim F_{\left(\mathrm{db}_{1}=v_{1} ; \mathrm{db}_{2}=v_{2}\right)}$ di mana $v_{1}=n^{\prime}-1$ dan $v_{2}=n^{\prime \prime}-1$ dengan $n$ ' adalah banyaknya sampel pada ragam sampel hasil dari fungsi $\max \left\{S_{1}^{2}, S_{2}^{2}\right\}$ dan $n$ " adalah banyaknya sampel pada ragam sampel hasil dari fungsi $\min \left\{S_{1}^{2}, S_{2}^{2}\right\}$. Pada taraf nyata $\alpha$, kedua ragam populasi dianggap sama apabila

- $F_{\text {hitung }}>F_{\left(\mathrm{db}_{1}=\mathrm{v}_{1} ; \mathrm{db}_{2}=\mathrm{v}_{2} ; \alpha / 2\right)}$ atau

- $F_{\text {hitung }}<F_{\left(\mathrm{db}_{1}=\mathrm{v}_{1} ; \mathrm{db}_{2}=\mathrm{v}_{2} ; 1-\alpha / 2\right)}$

dengan $\mathrm{F}_{\left(\mathrm{db}_{1}=\mathrm{v}_{1} ; \mathrm{db}_{2}=\mathrm{v}_{2} ; \alpha / 2\right)}$ dan $\mathrm{F}_{\left(\mathrm{db}_{1}=\mathrm{v}_{1} ; \mathrm{db}_{2}=\mathrm{v}_{2} ; 1-\alpha / 2\right)}$ masing-masing adalah persentil ke $(1-\alpha / 2) \times 100$ dan

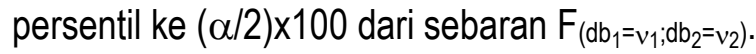


Apabila dari hasil Uji F kedua ragam populasi dapat dianggap sama maka formula statistik uji thitung menjadi

$$
\mathrm{t}_{\text {hitung }}=\frac{\left(\overline{\mathrm{X}}_{1}-\overline{\mathrm{X}}_{2}\right)}{\mathrm{S}_{\mathrm{gab}}\left(\frac{1}{\mathrm{n}_{1}}+\frac{1}{\mathrm{n}_{2}}\right)} ; \mathrm{S}_{\mathrm{gab}}^{2}=\frac{\left(\mathrm{n}_{1}-1\right) \mathrm{S}_{1}^{2}+\left(\mathrm{n}_{2}-1\right) \mathrm{S}_{2}^{2}}{\mathrm{n}_{1}+\mathrm{n}_{2}-2}
$$

dengan $t_{\text {hitung }} \sim \mathrm{t}_{\left(\mathrm{db}=\mathrm{n}_{1}-\mathrm{n}_{2}-2\right)}$ di mana $\mathrm{n}_{1}$ dan $\mathrm{n}_{2}$ masing-masing adalah banyaknya sampel yang diambil dari populasi 1 dan populasi 2. Apabila kedua ragam populasi tidak dapat dianggap sama maka formula statistik uji thitung menjadi

$$
\mathrm{t}_{\text {hitung }}=\frac{\left(\overline{\mathrm{X}}_{1}-\overline{\mathrm{X}}_{2}\right)}{\sqrt{\frac{\mathrm{S}_{1}^{2}}{\mathrm{n}_{1}}+\frac{\mathrm{S}_{2}^{2}}{\mathrm{n}_{2}}}}
$$

dengan $t_{\text {hitung }} \sim \mathrm{t}_{(\mathrm{db}=\mathrm{v})}$ di mana

$$
v=\frac{\left(\mathrm{S}_{1}^{2} / \mathrm{n}_{1}+\mathrm{S}_{2}^{2} / \mathrm{n}_{2}\right)^{2}}{\frac{\left(\mathrm{S}_{1}^{2} / \mathrm{n}_{1}\right)^{2}}{\mathrm{n}_{1}-1}+\frac{\left(\mathrm{S}_{2}^{2} / \mathrm{n}_{2}\right)^{2}}{\mathrm{n}_{2}-1}}
$$

Nilai-p bagi ketiga tipe hipotesis nilai tengah dua populasi adalah:
a. $\mathrm{H}_{0}: \mu_{1}-\mu_{2} \leq 0$ vs $\mathrm{H}_{1}: \mu_{1}-\mu_{2}>0 \quad \rightarrow$ Nilai- $\mathrm{p}=\mathrm{P}\left(\mathrm{t}>\mathrm{t}_{\text {hitung }}\right)$
b. $H_{0}: \mu_{1}-\mu_{2} \geq 0$ vs $H_{1}: \mu_{1}-\mu_{2}<0 \quad \rightarrow$ Nilai- $p=P\left(t<t_{\text {hitung }}\right)$
c. $H_{0}: \mu_{1}-\mu_{2}=0$ vs $H_{1}: \mu_{1}-\mu_{2} \neq 0 \quad \rightarrow$ Nilai- $p=2 P\left(t>\left|t_{\text {hitung }}\right|\right)$
Hipotesis $\mathrm{H}_{0}$ ditolak apabila nilai-p lebih kecil dari taraf nyata $\alpha$ yang ditetapkan.

\section{METODOLOGI}

Penelitian ini dilakukan melalui kajian simulasi. Berikut ini beberapa faktor yang akan dikaji pengaruhnya pada ketegaran terhadap ketidaknormalan dari Uji t.

1. Sebaran data

Berkaitan dengan sebaran data, terdapat tiga tipe sebaran yang akan dicobakan, yaitu sebaran normal, sebaran simetris bukan normal, dan sebaran tidak simetris bukan normal. Karena populasi yang dihadapi ada dua maka dapat disusun enam kemungkinan pasangan sebaran populasi seperti disajikan pada Tabel 1.

2. Ragam populasi

Pada penjelasan mengenai Uji t dikemukakan dua tipe penghitungan statistik uji thitung yang tergantung ragam dua populasi yang diuji. Merupakan hal yang menarik untuk membandingkan ketegaran dua tipe penghitungan statistik uji thitung ini. Oleh karena itu, untuk menelusuri pengaruh ragam dua populasi akan dicobakan kedua ragam populasi sama dan tidak sama pada simulasi yang dilakukan. 
Tabel 1. Enam Kemungkinan Pasangan Sebaran Populasi

\begin{tabular}{cll}
\hline Kemungkinan & \multicolumn{1}{c}{ Populasi 1 } & \multicolumn{1}{c}{ Populasi 2 } \\
\hline 1 & Sebaran normal & Sebaran normal \\
2 & Sebaran normal & Simetris bukan normal \\
3 & Sebaran normal & Tidak simetris bukan normal \\
4 & Simetris bukan normal & Simetris bukan normal \\
5 & Simetris bukan normal & Tidak simetris bukan normal \\
6 & Tidak simetris bukan normal & Tidak simetris bukan normal \\
\hline
\end{tabular}

3. Ukuran sampel

Faktor ukuran sampel ini digunakan untuk menelusuri apakah ketegaran Uji t juga tergantung dari ukuran sampel yang diambil. Simulasi yang dilakukan akan dicobakan ukuran sampel $\mathrm{n}=$ $10,15,25,40,50$, dan 100. Pemilihan besarnya ukuran sampel ini sedemikian rupa untuk dapat mewakili ukuran sampel kecil sampai besar.

Dari ketiga faktor tersebut, faktor sebaran data dan ragam populasi merupakan faktor yang berkaitan dengan pembangkitan populasi. Apabila kedua faktor ini dikombinasikan maka akan didapatkan duabelas kemungkinan pasangan sebaran populasi seperti ditampilkan pada Tabel 2. Keduabelas kemungkinan pasangan populasi tersebut dibangkitkan pada kondisi $\mathrm{H}_{0}$ benar, yaitu $\mu_{1}=$ $\mu_{2}$. Tabel 3 memberikan uraian keduabelas kemungkinan pasangan populasi tersebut dengan $Y_{1}$ dan $Y_{2}$ berturut-turut adalah sebaran dari populasi pertama dan kedua.

Selanjutnya, langkah yang digunakan di dalam simulasi yang akan dilakukan adalah sebagai berikut.

1. Pembangkitan populasi.

Pada tahapan ini, populasi yang akan dibangkitkan adalah sebanyak duabelas pasangan populasi seperti yang telah dikemukakan.

2. Penarikan sampel dari populasi

Setelah data populasi dibangkitkan pada Langkah 1, dari masing-masing populasi akan ditarik sampel sebanyak $n$ dengan berbagai kemungkinan $n$ seperti dijelaskan pada faktor ukuran sampel.

3. Pengujian dengan Uji t

Setelah sampel diperoleh dari masing-masing populasi, langkah berikutnya adalah menguji dengan Uji t. Taraf nyata pengujian ditentukan sebesar $5 \%$.

Pada simulasi yang akan dilakukan, Langkah 2 dan 3 diulang sebanyak 10000 kali. Dari 10000 pengulangan ini, proporsi penolakan $\mathrm{H}_{0}$ pada Uji t yang dilakukan dibandingkan dengan taraf nyata $5 \%$ yang digunakan. Proporsi penolakan $\mathrm{H}_{0}$ yang tidak sama dengan $5 \%$ merupakan indikasi Uji t tidak tegar.

\section{HASIL DAN PEMBAHASAN}

\section{Deskripsi Populasi Hasil Simulasi}

Dari Tabel 4 yang menyajikan deskripsi keduabelas pasang populasi yang dibangkitkan terlihat bahwa masing-masing pasangan populasi pada keduabelas pasang populasi tersebut dapat 
dikatakan memiliki rata-rata yang sama besar. Dengan demikian dapat disimpulkan bahwa nilai tengah masing-masing pasangan populasi berada di bawah $\mathrm{H}_{0}$. Selain itu, dari besarnya simpangan baku terlihat bahwa keenam pasangan populasi pertama dapat dikatakan memiliki ragam yang sama besar, sedangkan enam pasangan populasi berikutnya memiliki ragam yang tidak sama. Selanjutnya, dari Gambar 1 yang menyajikan perbandingan sebaran antar masing-masing pasang populasi dari keduabelas pasang populasi yang dibangkitkan terlihat bahwa keduabelas pasangan populasi yang dibangkitkan masing-masing memiliki nilai tengah yang sama. Dari Gambar 1 juga terlihat bahwa enam pasang populasi pertama memiliki ragam yang sama besar, sedangkan enam pasang populasi berikutnya memiliki ragam yang berbeda. Gambar 1 juga menginformasikan pola kesimetrisan sebaran populasi. Sebagai contoh, gambar Pasangan Populasi 2, di mana sebaran Gamma $(200,1)$ relatif simetris bila dibandingkan dengan sebaran Normal $(200,200)$ pasangannya. Demikian pula untuk gambar Pasangan Populasi 3 di mana sebaran Gamma $(35,1)$ lebih menjulur ke kanan apabila dibandingkan dengan sebaran Normal $(35,35)$ pasangannya. Dengan demikian pola kesimetrisan sebaran populasi yang dibangkitkan sesuai dengan skenario sebagaimana diuraikan pada Tabel 2.

Tabel 2. Duabelas Kemungkinan Pasangan Sebaran Populasi

\begin{tabular}{ccll}
\hline Kemungkinan & Ragam dua populasi & \multicolumn{1}{c}{ Populasi 1 } & \multicolumn{1}{c}{ Populasi 2 } \\
\hline 1 & Sama & Sebaran normal & Sebaran normal \\
2 & Sama & Sebaran normal & Simetris bukan normal \\
3 & Sama & Sebaran normal & Tidak simetris bukan normal \\
4 & Sama & Simetris bukan normal & Simetris bukan normal \\
5 & Sama & Simetris bukan normal & Tidak simetris bukan normal \\
6 & Sama & Tidak simetris bukan normal & Tidak simetris bukan normal \\
7 & Tidak sama & Sebaran normal & Sebaran normal \\
8 & Tidak sama & Sebaran normal & Simetris bukan normal \\
9 & Tidak sama & Sebaran normal & Tidak simetris bukan normal \\
10 & Tidak sama & Simetris bukan normal & Simetris bukan normal \\
11 & Tidak sama & Simetris bukan normal & Tidak simetris bukan normal \\
12 & Tidak sama & Tidak simetris bukan normal & Tidak simetris bukan normal \\
\hline
\end{tabular}

Tabel 3. Uraian Keduabelas Kemungkinan Pasangan Populasi

\begin{tabular}{|c|c|c|}
\hline Pasangan & Populasi 1 & $\begin{array}{r}\text { Populasi } 2 \\
\end{array}$ \\
\hline 1 & $Y_{1} \sim \operatorname{Normal}(5,25)$ & $\mathrm{Y}_{2} \sim \operatorname{Normal}(5,25)$ \\
\hline 2 & $Y_{1} \sim \operatorname{Normal}(200,200)$ & $Y_{2} \sim \operatorname{Gamma}(200,1)$ \\
\hline 3 & $Y_{1} \sim \operatorname{Normal}(35,35)$ & $\mathrm{Y}_{2} \sim \operatorname{Gamma}(35,1)$ \\
\hline 4 & $Y_{1} \sim \operatorname{Gamma}(200,1)$ & $Y_{2} \sim \operatorname{Gamma}(200,1)$ \\
\hline 5 & $Y_{1} \sim \operatorname{Gamma}(200,1)$ & $Y_{2}=160+5 X 2$, dengan $X_{2} \sim \operatorname{Gamma}(8,1)$ \\
\hline 6 & $Y_{1} \sim \operatorname{Gamma}(35,1)$ & $\mathrm{Y}_{2} \sim \operatorname{Gamma}(35,1)$ \\
\hline 7 & $Y_{1} \sim \operatorname{Normal}(5,25)$ & $\mathrm{Y}_{2} \sim \operatorname{Normal}(5,125)$ \\
\hline 8 & $Y_{1} \sim \operatorname{Normal}(200,1000)$ & $Y_{2} \sim \operatorname{Gamma}(200,1)$ \\
\hline 9 & $Y_{1} \sim \operatorname{Normal}(35,175)$ & $\mathrm{Y}_{2} \sim \operatorname{Gamma}(35,1)$ \\
\hline 10 & $Y_{1} \sim \operatorname{Gamma}(200,1)$ & $Y_{2}=-247.214+\sqrt{5} X_{2}$ dengan $X_{2} \sim \operatorname{Gamma}(200,1)$ \\
\hline 11 & $Y_{1} \sim \operatorname{Gamma}(200,1)$ & $Y_{2}=110.557+\sqrt{ } 125 X_{2}$, dengan $X_{2} \sim \operatorname{Gamma}(8,1)$ \\
\hline 12 & $Y_{1} \sim \operatorname{Gamma}(35,1)$ & $Y_{2}=-43.262+\sqrt{5} X_{2}$ dengan $X_{2} \sim \operatorname{Gamma}(35,1)$ \\
\hline
\end{tabular}


Jurnal Matematika, Sains, dan Teknologi, Voume 7, Nomor 1, Maret 2006, 1 - 10

Tabel 4. Deskripsi Populasi Hasil Simulasi

\begin{tabular}{crrrr}
\hline \multirow{2}{*}{ Pasangan populasi } & \multicolumn{2}{c}{ Rata-rata } & \multicolumn{2}{c}{ Simpangan baku } \\
\cline { 2 - 5 } & Populasi 1 & Populasi 2 & Populasi 1 & Populasi 2 \\
\hline 1 & 4.92 & 4.92 & 4.98 & 4.98 \\
2 & 199.92 & 200.05 & 14.10 & 14.16 \\
3 & 34.93 & 35.03 & 5.94 & 5.91 \\
4 & 200.05 & 200.05 & 14.16 & 14.16 \\
5 & 200.05 & 200.05 & 14.16 & 14.27 \\
6 & 35.03 & 35.03 & 5.91 & 5.91 \\
7 & 4.92 & 5.08 & 4.98 & 11.06 \\
8 & 200.13 & 200.05 & 31.53 & 14.16 \\
9 & 35.10 & 35.03 & 13.34 & 5.91 \\
10 & 200.05 & 200.10 & 14.16 & 31.67 \\
11 & 200.05 & 200.12 & 14.16 & 31.90 \\
12 & 35.03 & 35.06 & 5.91 & 13.22 \\
\hline
\end{tabular}
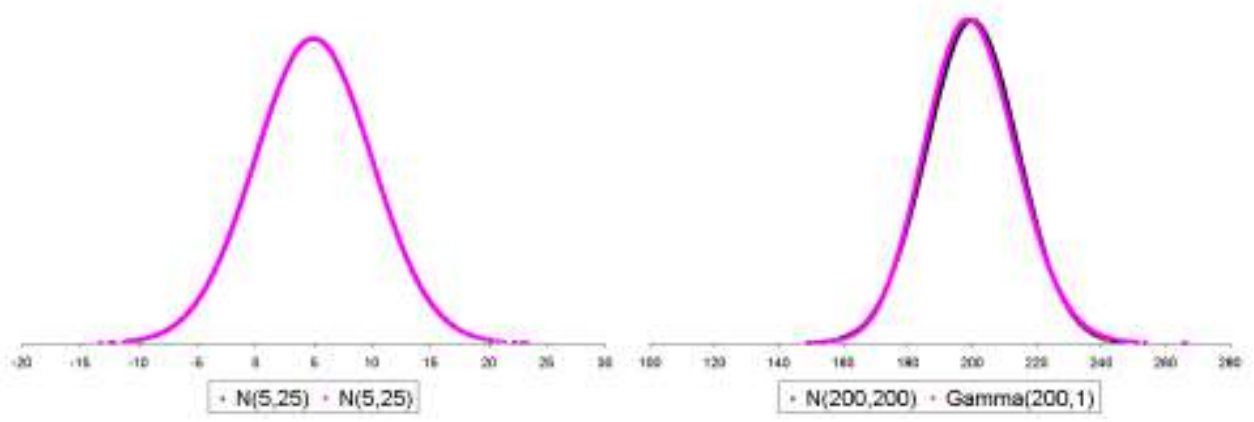

(a) Pasangan Populasi 1

(b) Pasangan Populasi 2
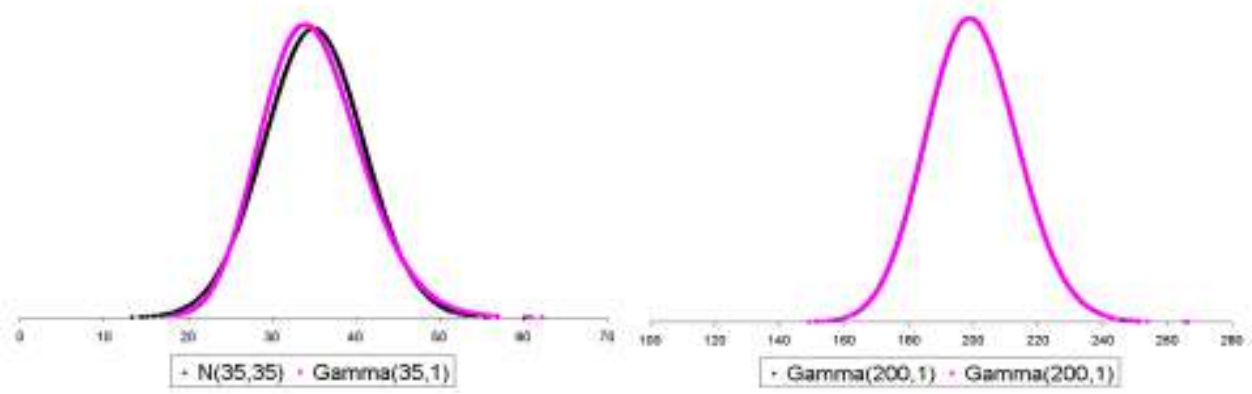

(c) Pasangan Populasi 3

(d) Pasangan Populasi 4 


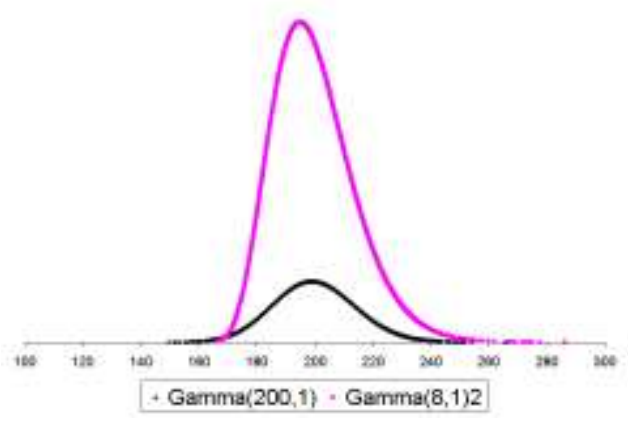

(e) Pasangan Populasi 5

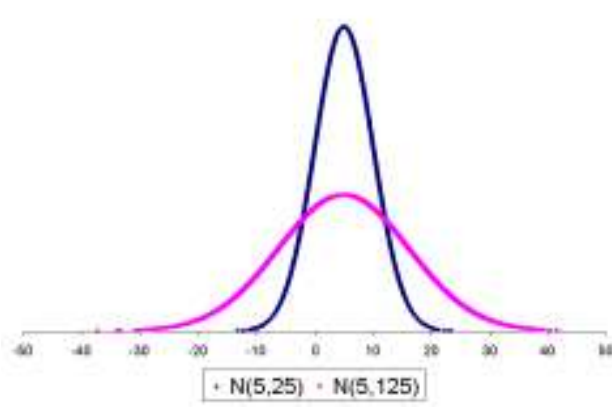

(g) Pasangan Populasi 7

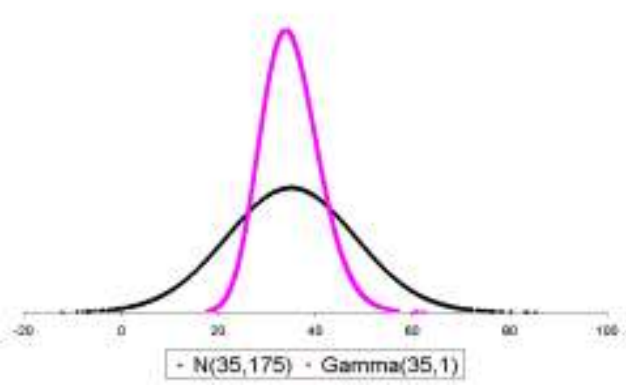

(i) Pasangan Populasi 9

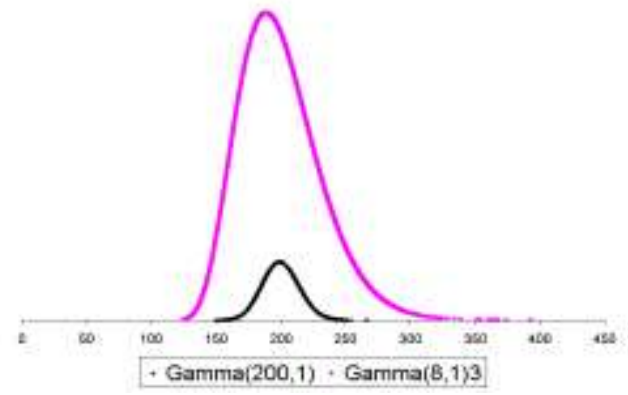

(k) Pasangan Populasi 11

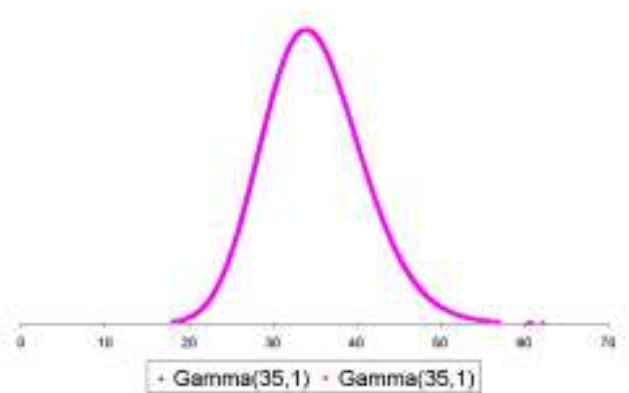

(f) Pasangan Populasi 6

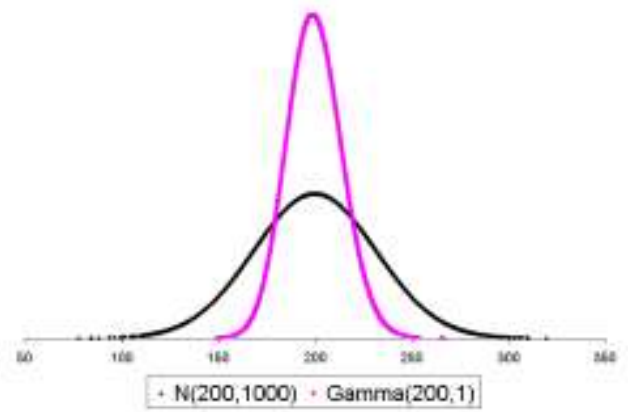

(h) Pasangan Populasi 8

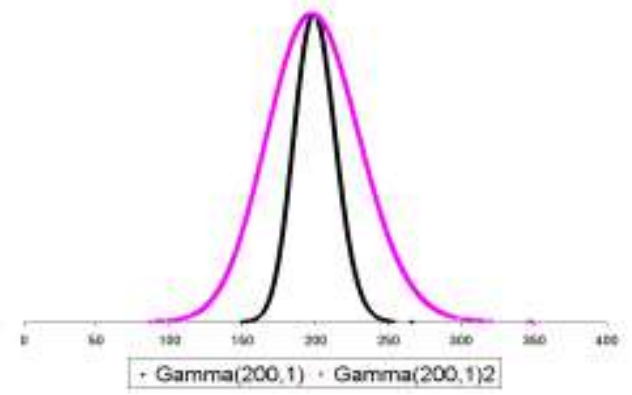

(j) Pasangan Populasi 10

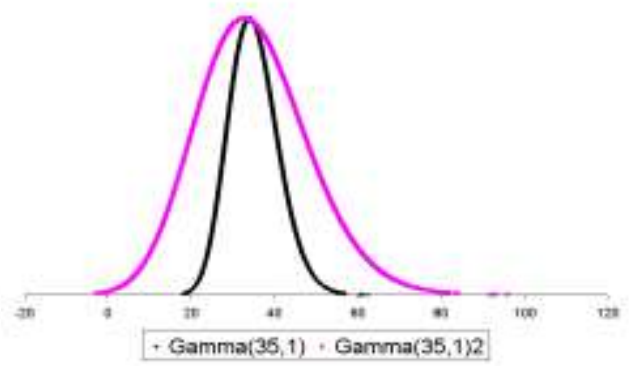

(I) Pasangan Populasi 12

Gambar 1. Perbandingan Pola Sebaran Keduabelas Pasangan Populasi yang Dibangkitkan 


\section{Performa Uji t}

Evaluasi terhadap performa Uji t yang dilihat dari proporsi penolakan $\mathrm{H}_{0}$ dari 10.000 ulangan disajikan pada Tabel 5. Pada Tabel yang dimaksudkan dengan 'Cara 1' adalah bahwa prosedur pengujian Uji t dilakukan dengan anggapan ragam kedua populasi seperti pada Tabel 2. Dengan kata lain, keenam pasang populasi pertama diuji dengan anggapan ragam kedua populasi sama, sedangkan keenam populasi berikutnya diuji dengan anggapan ragam kedua populasi tidak sama. Sedangkan untuk 'Cara 2', prosedur pengujian Uji t dilakukan dengan terlebih dahulu menguji kesamaan ragam kedua populasi. Sehingga untuk 'Cara 2' ini, apapun kondisi ragam kedua populasi, apabila dari pengujian kesamaan ragam ini diperoleh kesimpulan bahwa ragam kedua populasi sama maka pengujian Uji t dilakukan dengan anggapan ragam kedua populasi sama. Demikian pula sebaliknya, apabila dari pengujian kesamaan ragam ini diperoleh kesimpulan bahwa ragam kedua populasi tidak sama maka pengujian Uji t dilakukan dengan anggapan ragam kedua populasi tidak sama.

Dari Tabel 5 terlihat bahwa besarnya proporsi penolakan $\mathrm{H}_{0}$, baik untuk 'Cara 1' maupun 'Cara 2', dapat dikatakan sama besar. Hal ini menunjukkan bahwa Uji F yang digunakan untuk mengevaluasi kesamaan ragam kedua populasi sebelum dilakukan Uji t, sebagaimana prosedur pada 'Cara 2', memiliki kuasa uji yang cukup baik. Selain itu, hal ini juga menunjukkan bahwa data hasil pembangkitan, khususnya dalam hal pembandingan keragaman kedua populasi, telah memenuhi skenario seperti yang dikemukakan pada Tabel 2 .

Secara umum dari Tabel 5 dapat dilihat bahwa besarnya proporsi penolakan $\mathrm{H}_{0}$ untuk ketiga tipe $\mathrm{H}_{1}$, baik untuk pasangan populasi dengan ragam sama maupun tidak sama, berada di sekitar nilai 0.05 yang merupakan besarnya taraf nyata pengujian yang digunakan dalam simulasi. Hal ini menunjukkan bahwa Uji t untuk pengujian nilai tengah dua populasi tegar terhadap ketidaknormalan data. Tidak berbedanya proporsi penolakan $\mathrm{H}_{0}$ pada Tabel 5 menunjukkan bahwa faktor ragam populasi tidak memiliki pengaruh terhadap ketegaran Uji t. Dengan kata lain, prosedur pengujian Uji t, baik dengan anggapan ragam kedua populasi sama maupun tidak sama, memiliki ketegaran yang tidak berbeda. Hal serupa juga nampak pada faktor ukuran sampel yang terlihat dari tidak adanya pola sistematis tertentu dari besarnya proporsi penolakan $\mathrm{H}_{0}$ untuk berbagai ukuran sampel yang dicobakan.

Hal ini kemungkinan disebabkan oleh adanya dalil Limit Pusat. Dalil Limit Pusat pada dasarnya mengemukakan konvergensi sebaran statistik rata-rata dari sembarang populasi yang mengarah ke sebaran normal untuk limit ukuran sampel yang tak hingga. Dengan kata lain, dalil ini mengungkapkan bahwa statistik rata-rata akan menyebar normal untuk ukuran sampel yang tak hingga, apapun sebaran dari populasi asal statistik rata-rata. Ukuran sampel tak hingga sebagai syarat teoritis konvergensi sebaran statistik rata-rata ini dipahami secara praktis sebagai ukuran sampel yang besar. Dengan demikian dari dalil ini dapat disimpulkan bahwa untuk ukuran sampel yang besar statistik rata-rata akan menyebar normal apapun kondisi sebaran dari populasi asal di mana sampel ditarik. Kriteria kapan ukuran sampel dikatakan besar, dapat berbeda tergantung dari sebaran populasi asal. Sebagai sampel, untuk sebaran t, ukuran sampel sebesar 30 dapat dianggap besar karena dengan sampel sebanyak itu sebaran normal dapat mengaproksimasi sebaran $\mathrm{t}$ dengan cukup baik.

Selanjutnya, uji t untuk pengujian nilai tengah dua populasi mendasarkan penghitungan statistik t-hitungnya pada sebaran statistik selisih rata-rata sampel dua populasi. Pada Tabel 6 disajikan nilai-p hasil pengujian kenormalan dengan Uji Anderson-Darling terhadap sebaran statistik 
selisih rata-rata sampel dua populasi dari keduabelas pasang populasi. Secara umum dari Tabel 6 dapat disimpulkan bahwa sebaran statistik selisih rata-rata sampel dua populasi adalah normal walaupun populasi asalnya (baik salah satu populasi maupun keduanya) tidak menyebar normal. Dengan demikian, uji t untuk pengujian nilai tengah dua populasi yang tegar atau tidak dipengaruhi oleh ketidaknormalan sebaran populasi asal dapat dipahami sebagai konsekuensi dari sebaran statistik rata-rata sampel dua populasi yang menyebar normal walaupun populasi asalnya tidak normal.

Tabel 5. Proporsi Penolakan $\mathrm{H}_{0}$ Uji t dari 10000 Ulangan untuk Keduabelas Pasangan Populasi

\begin{tabular}{|c|c|c|c|c|c|c|c|c|c|c|c|c|c|c|c|}
\hline \multirow{3}{*}{$\begin{array}{c}\text { Pasangan } \\
\text { populasi }\end{array}$} & \multirow{3}{*}{$\mathrm{n}$} & \multicolumn{6}{|c|}{ Tipe $\mathrm{H}_{1}$} & \multirow{3}{*}{$\begin{array}{l}\text { Pasangan } \\
\text { - populasi }\end{array}$} & \multirow{3}{*}{$\mathrm{n}$} & \multicolumn{6}{|c|}{ Tipe $\mathrm{H}_{1}$} \\
\hline & & \multicolumn{2}{|c|}{$\mu_{1}<\mu_{2}$} & \multicolumn{2}{|c|}{$\mu_{1}>\mu_{2}$} & \multicolumn{2}{|c|}{$\mu_{1} \neq \mu_{2}$} & & & \multicolumn{2}{|c|}{$\mu_{1}<\mu_{2}$} & \multicolumn{2}{|c|}{$\mu_{1}>\mu_{2}$} & \multicolumn{2}{|c|}{$\mu_{1} \neq \mu_{2}$} \\
\hline & & Cara 1 & Cara 2 & Cara 1 & Cara 2 & Cara 1 & Cara 2 & & & Cara 1 & Cara 2 & Cara 1 & Cara 2 & Cara 1 & Cara 2 \\
\hline \multirow[t]{6}{*}{1} & 10 & 0.0492 & 0.0488 & 0.0564 & 0.0563 & 0.0512 & 0.0503 & 7 & 10 & 0.0493 & 0.0495 & 0.0454 & 0.0455 & 0.0489 & 0.0495 \\
\hline & 15 & 0.0524 & 0.0522 & 0.0492 & 0.0490 & 0.0498 & 0.0490 & & 15 & 0.0565 & 0.0565 & 0.0481 & 0.0482 & 0.0508 & 0.0509 \\
\hline & 25 & 0.0510 & 0.0509 & 0.0516 & 0.0516 & 0.0477 & 0.0476 & & 25 & 0.0554 & 0.0554 & 0.0448 & 0.0448 & 0.0529 & 0.0529 \\
\hline & 40 & 0.0472 & 0.0472 & 0.0464 & 0.0464 & 0.0419 & 0.0419 & & 40 & 0.0589 & 0.0589 & 0.0453 & 0.0453 & 0.0544 & 0.0544 \\
\hline & 50 & 0.0467 & 0.0467 & 0.0520 & 0.0520 & 0.0469 & 0.0469 & & 50 & 0.0611 & 0.0611 & 0.0425 & 0.0425 & 0.0526 & 0.0526 \\
\hline & 100 & 0.0500 & 0.0500 & 0.0520 & 0.0520 & 0.0497 & 0.0497 & & 100 & 0.0637 & 0.0637 & 0.0363 & 0.0363 & 0.0519 & 0.0519 \\
\hline \multirow[t]{6}{*}{2} & 10 & 0.0496 & 0.0489 & 0.0524 & 0.0522 & 0.0491 & 0.0487 & 8 & 10 & 0.0447 & 0.0450 & 0.0518 & 0.0521 & 0.0500 & 0.0505 \\
\hline & 15 & 0.0486 & 0.0486 & 0.0518 & 0.0516 & 0.0499 & 0.0494 & & 15 & 0.0467 & 0.0467 & 0.0562 & 0.0562 & 0.0510 & 0.0510 \\
\hline & 25 & 0.0542 & 0.0542 & 0.0476 & 0.0476 & 0.0492 & 0.0492 & & 25 & 0.0503 & 0.0503 & 0.0524 & 0.0524 & 0.0481 & 0.0481 \\
\hline & 40 & 0.0542 & 0.0542 & 0.0471 & 0.0471 & 0.0494 & 0.0493 & & 40 & 0.0501 & 0.0501 & 0.0509 & 0.0509 & 0.0500 & 0.0500 \\
\hline & 50 & 0.0534 & 0.0534 & 0.0429 & 0.0429 & 0.0487 & 0.0486 & & 50 & 0.0499 & 0.0499 & 0.0544 & 0.0544 & 0.0514 & 0.0514 \\
\hline & 100 & 0.0549 & 0.0549 & 0.0458 & 0.0458 & 0.0510 & 0.0510 & & 100 & 0.0470 & 0.0470 & 0.0528 & 0.0528 & 0.0486 & 0.0486 \\
\hline \multirow[t]{6}{*}{3} & 10 & 0.0503 & 0.0502 & 0.0513 & 0.0512 & 0.0492 & 0.0482 & 9 & 10 & 0.0498 & 0.0501 & 0.0530 & 0.0530 & 0.0568 & 0.0576 \\
\hline & 15 & 0.0504 & 0.0504 & 0.0482 & 0.0479 & 0.0494 & 0.0493 & & 15 & 0.0456 & 0.0458 & 0.0472 & 0.0472 & 0.0474 & 0.0475 \\
\hline & 25 & 0.0521 & 0.0520 & 0.0479 & 0.0478 & 0.0479 & 0.0479 & & 25 & 0.0449 & 0.0449 & 0.0529 & 0.0529 & 0.0480 & 0.0480 \\
\hline & 40 & & 0.05 & & 0.04 & & & & 40 & & & & & 521 & \\
\hline & 50 & 0.0525 & 0.0525 & 0.0425 & 0.0425 & 0.0457 & 0.0457 & & 50 & 0.0434 & 0.0434 & 0.0557 & 0.0557 & 0.0494 & 0.0494 \\
\hline & 100 & 0.0618 & 0.0618 & 0.0392 & 0.0392 & 0.0510 & 0.0510 & & 100 & 0.0452 & 0.0452 & 0.0513 & 0.0513 & 0.0464 & 0.0464 \\
\hline \multirow[t]{6}{*}{4} & 10 & 0.0491 & 0.0488 & 0.0504 & 0.0501 & 0.0525 & 0.0517 & 10 & 10 & 0.0460 & 0.0460 & 0.0546 & 0.0549 & 0.0513 & 0.0518 \\
\hline & 15 & 0.0517 & 0.0516 & 0.0517 & 0.0516 & 0.0536 & 0.0534 & & 15 & 0.0460 & 0.0460 & 0.0497 & 0.0497 & 0.0486 & 0.0487 \\
\hline & 25 & 0.0492 & 0.0492 & 0.0497 & 0.0496 & 0.0516 & 0.0516 & & 25 & 0.0479 & 0.0479 & 0.0484 & 0.0484 & 0.0490 & 0.0490 \\
\hline & 40 & 0.0517 & 0.0517 & 0.0510 & 0.0509 & 0.0514 & 0.0513 & & 40 & 0.0492 & 0.0492 & 0.0523 & 0.0523 & 0.0523 & 0.0523 \\
\hline & 50 & 0.0494 & 0.0494 & 0.0482 & 0.0482 & 0.0490 & 0.0490 & & 50 & 0.0476 & 0.0476 & 0.0529 & 0.0529 & 0.0482 & 0.0482 \\
\hline & 100 & 0.0512 & 0.0512 & 0.0493 & 0.0493 & 0.0509 & 0.0509 & & 100 & 0.0497 & 0.0497 & 0.0524 & 0.0524 & 0.0503 & 0.0503 \\
\hline \multirow[t]{6}{*}{5} & 10 & 0.0449 & 0.0448 & 0.0556 & 0.0554 & 0.0476 & 0.0469 & 11 & 10 & 0.0354 & 0.0354 & 0.0621 & 0.0623 & 0.0500 & 0.0509 \\
\hline & 15 & 0.0472 & 0.0469 & 0.0571 & 0.0569 & 0.0545 & 0.0538 & & 15 & 0.0400 & 0.0400 & 0.0673 & 0.0674 & 0.0571 & 0.0572 \\
\hline & 25 & 0.0454 & 0.0454 & 0.0576 & 0.0575 & 0.0503 & 0.0499 & & 25 & 0.0415 & 0.0415 & 0.0578 & 0.0578 & 0.0490 & 0.0490 \\
\hline & 40 & 0.0497 & 0.0496 & 0.0547 & 0.0547 & 0.0512 & 0.0511 & & 40 & 0.0412 & 0.0412 & 0.0586 & 0.0586 & 0.0525 & 0.0525 \\
\hline & 50 & 0.0463 & 0.0463 & 0.0512 & 0.0511 & 0.0519 & 0.0518 & & 50 & 0.0417 & 0.0417 & 0.0576 & 0.0576 & 0.0530 & 0.0530 \\
\hline & 100 & 0.0471 & 0.0471 & 0.0465 & 0.0465 & 0.0431 & 0.0431 & & 100 & 0.0453 & 0.0453 & 0.0548 & 0.0548 & 0.0498 & 0.0498 \\
\hline \multirow[t]{6}{*}{6} & 10 & 0.0521 & 0.0517 & 0.0489 & 0.0486 & 0.0491 & 0.0481 & 12 & 10 & 0.0426 & 0.0427 & 0.0620 & 0.0623 & 0.0534 & 0.0537 \\
\hline & 15 & 0.0457 & 0.0455 & 0.0520 & 0.0519 & 0.0475 & 0.0470 & & 15 & 0.0440 & 0.0440 & 0.0559 & 0.0559 & 0.0490 & 0.0493 \\
\hline & 25 & 0.0476 & 0.0476 & 0.0516 & 0.0516 & 0.0506 & 0.0504 & & 25 & 0.0499 & 0.0499 & 0.0547 & 0.0547 & 0.0531 & 0.0532 \\
\hline & 40 & 0.0485 & 0.0484 & 0.0497 & 0.0496 & 0.0500 & 0.0500 & & 40 & 0.0465 & 0.0465 & 0.0496 & 0.0496 & 0.0465 & 0.0465 \\
\hline & 50 & 0.0503 & 0.0503 & 0.0499 & 0.0499 & 0.0509 & 0.0509 & & 50 & 0.0486 & 0.0486 & 0.0517 & 0.0517 & 0.0485 & 0.0485 \\
\hline & 100 & 0.0503 & 0.0503 & 0.0518 & 0.0518 & 0.0494 & 0.0494 & & 100 & 0.0489 & 0.0489 & 0.0491 & 0.0491 & 0.0495 & 0.0495 \\
\hline
\end{tabular}


Tabel 6. Nilai-p Hasil Pengujian Kenormalan terhadap Sebaran Statistik Selisih Rata-rata Sampel Dua Populasi dari Keduabelas Pasangan Populasi

\begin{tabular}{ccccccc}
\hline \multirow{2}{*}{ Pasangan } & \multicolumn{7}{c}{$\mathrm{n}$} \\
\cline { 2 - 7 } & 10 & 15 & 25 & 40 & 50 & 100 \\
\hline 1 & 0.7059 & 0.8294 & 0.0641 & 0.3819 & 0.9602 & 0.5812 \\
2 & 0.6141 & 0.7916 & 0.3820 & 0.6328 & 0.7991 & 0.5914 \\
3 & 0.2724 & 0.2385 & 0.6547 & 0.4528 & 0.2527 & 0.4797 \\
4 & 0.5618 & 0.1805 & 0.8603 & 0.6974 & 0.1128 & 0.9842 \\
5 & 0.1723 & 0.1838 & 0.2059 & 0.6810 & 0.5020 & 0.6048 \\
6 & 0.5112 & 0.9020 & 0.2681 & 0.1946 & 0.0523 & 0.4429 \\
7 & 0.3289 & 0.8539 & 0.3636 & 0.9084 & 0.3077 & 0.3977 \\
8 & 0.5211 & 0.8749 & 0.6123 & 0.2772 & 0.8412 & 0.2414 \\
9 & 0.5017 & 0.4826 & 0.1524 & 0.6660 & 0.5928 & 0.0961 \\
10 & 0.2447 & 0.5095 & 0.7167 & 0.2142 & 0.1182 & 0.8192 \\
11 & 0.1420 & 0.0595 & 0.1319 & 0.2273 & 0.8924 & 0.1542 \\
12 & 0.6977 & 0.0730 & 0.0816 & 0.5318 & 0.3093 & 0.6976 \\
\hline
\end{tabular}

\section{PENUTUP}

Hasil simulasi menunjukkan bahwa Uji t untuk pengujian nilai tengah dua populasi adalah tegar terhadap ketidaknormalan data. Ketegaran ini tidak dipengaruhi oleh ragam kedua populasi serta ukuran sampel. Pada kajian sebaran dari statistik selisih rata-rata sampel dua populasi disimpulkan bahwa sebarannya adalah normal. Dengan demikian, ketegaran terhadap ketidaknormalan dari uji t tersebut dipahami sebagai konsekuensi dari selisih rata-rata sampel dua populasi yang menyebar normal.

\section{REFERENSI}

Nasoetion, M. D. (2000). Uji F di bawah $\mathrm{H}_{0}$ ketika asumsi dilepaskan. Forum Statistika dan Komputasi (Edisi Khusus).

Suryabuanaputra, D. (2001). Normality test for non-normal and skewed population. Skripsi Jurusan Statistika (tidak dipublikasikan).

Siege, S. \& Castellan Jr., N. J. (1988). Nonparametric Statistics for the behavioral sciences (2 $\left.2^{\text {nd }} e d\right)$. New York: McGraw-Hill. 